\title{
Antimicrobial Susceptibility and Genetic Analysis of Campylobacter jejuni Isolated from Diarrhea Patients in Busan
}

\author{
Sun Hee Park, Byeong Jun Kim, Young Hee Kwon, \\ In Yeong Hwang, Gyung Hye Sung, Eun Hee Park, Sung Hyun Jin \\ Microbiology Team, Department of Infectious Disease Research, \\ Busan Metropolitan City Institute of Health \& Environment, Busan, Korea
}

Background: Campylobacter jejuni is an important food-borne pathogen that causes human gastroenteritis. This study was conducted to investigate the incidence of isolation, antimicrobial susceptibility pattern, and C. jejuni genotype from diarrhea patients in Busan, Korea.

Methods: A total of 97 C. jejuni were isolated from diarrhea patients during five food-borne outbreaks from 2014 to September 2017. Antimicrobial susceptibility tests were carried out by the broth microdilution method for ciprofloxacin (CIP), nalidixic acid (NAL), tetracycline (TET), chloramphenicol, azithromycin (AZI), erythromycin (ERY), streptomycin (STR), gentamicin, and telithromycin. To investigate C. jejuni genotypes, pulsed-field gel electrophoresis (PFGE) profile analysis was performed.

Results: The isolation rate of $C$. jejuni was $2.0 \%$ for the last 4 years and increased annually. Antimicrobial resistance rates of $C$. jejuni were shown to be in the order of NAL $(90.9 \%)$, CIP (89.4\%), TET (13.6\%), AZI $(3.0 \%)$, ERY (3.0\%), and STR (1.5\%). The proportion of multidrug-resistance was $18.2 \%$, and they commonly contained quinolones (CIP-NAL). Analysis of PFGE patterns of Smal-restricted DNA of C. jejuni isolates showed 17 clusters; cluster 11 was the major genotype pattern.

Conclusion: This study will provide useful data for the proper use of antimicrobials and the management of resistant $C$. jejuni. Also it will help to provide data for the epidemiological investigation of foodborne diseases caused by $C$. jejuni, which is expected to increase in the future. (Ann Clin Microbiol 2019;22:42-49)

Key Words: Antimicrobial susceptibility, Campylobacter jejuni, Pulsed-field gel electrophoresis

\section{INTRODUCTION}

Campylobacter는 극성 편모를 가지는 그람 음성의 나선형 간균으로, 증식을 위해서 3-10\%의 산소와 3-5\%의 이산화탄소 가 필요한 미호기성 세균이며 주로 $42^{\circ} \mathrm{C}$ 에서 증식하는 호열성 세균이다[1,2]. 현재까지 26개의 종, 9 개의 아종이 알려져 있으 며 이 중 C. jejuni와 C. coli가 인체 감염을 주로 유발하는 것으 로 알려져 있다. C. jejuni는 가금류, 소, 돼지 등에 많이 분포하 고 있고 조리하지 않거나 조리가 덜 된 가금류 등의 육류를 섭 취한 경우, 살균 처리되지 않은 생우유의 섭취 등으로 인해 감 염되며 다른 식중독 세균에 비해 500-800개 정도의 소량의 균 수로도 감염을 일으킬 수 있다[1]. Campylobacter에 오염된 식 품 등을 섭취한 경우 산성의 위를 통과하면서 대부분이 사멸되
지만 일부 생존한 Campylobacter는 장 상피세포 또는 점막에 부착하고 장내에 집락을 형성한 후 독소를 생산하여 분비성 설 사를 야기하거나 장 점막 내로 침입한 다음 증식하여 면역 반 응을 유발하고 출혈을 동반한 염증성 설사를 발생시킨다. 또한 복통, 권태감, 발열, 구토 등의 임상 증상을 나타내며, 일부 면 역 저하자에서는 자가면역 질환인 Guillain-Barre 증후군과 Miller Fisher 증후군 등을 일으키기도 한다[3].

캠필로박터증(Campylobacteriosis)은 대부분 임상 증상이 심 하지 않고, 증상의 지속 기간이 짧아 항균제 투여가 불필요하 나 심한 증상이나 패혈증 발병 환자 및 면역 저하자의 경우 감 염과 재발의 위험이 증가하며 만성 보균자가 될 가능성이 높으 므로 적절한 항균제 치료가 필요하다[1,2]. 이전에는 ciprofloxacin과 같은 quinolone계를 사용하였으나 1978년 벨기에에 
서 C. jejuni의 quinolone계 내성률이 $6.3 \%$ 임을 처음으로 보고 [4]한 이후 여러 국가에서 높은 내성률을 보고하고 있어 quinolone계 항균제 치료에 문제점이 제기되었으며 현재는 erythromycin, azithromycin과 같은 macrolide계 항균제가 주로 사용 되고 있다[1,2].

또한 Campylobacter의 감염 경로와 예방을 위한 역학적 연 구로 생물형, 혈청형, 파지형 등의 표현형을 분석하는 방법과 ribotyping, pulsed-field gel electrophoresis (PFGE), multilocus sequencing typing (MLST) 등 유전형을 분석하는 방법이 있다.

Campylobacter는 선진국에서는 살모넬라, 병원성 대장균과 함께 식품매개질환의 주요 원인 세균으로 알려져 있으나 국내 에서는 분리율이 낮아 그 중요성이 낮게 평가되어 왔다. 그러 나 최근 질병관리본부가 주관하는 급성설사질환 실험실 감시 사업(EnterNet)에서의 Campylobacter 분리율이 증가하고 있고 [5], Campylobacter에 의한 식중독이 매년 증가하고 있다. 이는 국내 축산물 소비량 증가, 학교 및 단체 급식 보급, 외식 문화 의 보편화 등의 식생활 변화와 기후 온난화 같은 환경적 변화 등에 의한 영향으로 향후 Campylobacter에 의한 식품매개질환 은 증가할 것으로 예상된다[5].

이에 본 연구에서는 부산지역 급성설사환자 실험실 감시사 업 및 식중독 환자에서 분리한 C. jejuni를 대상으로 항균제 감 수성 검사를 실시하여 내성 현황을 알아보고 PFGE로 유전자 형 분석을 실시하여 질환 발생 시 역학 연구의 기초 자료를 확 보하고자 하였다.

\section{MATERIALS AND METHODS}

\section{1. 연구대상}

2014년 1월부터 2017년 9월까지 부산지역 협력병원에 내원 한 설사환자 2,992 명의 대변 검체에서 분리된 C. jejuni 61주와
같은 기간 동안 발생한 5건의 식중독 사례에서 분리된 C. jejuni 36주를 포함하여 총 97주를 연구 대상으로 하였다. 식중독 사 례는 2015년 1건, 2017년 4건이 발생하였으며, 2015년 7월 고 등학교 집단급식소 발생 사례에서 C. jejuni 24주를 분리하였 고, 2017년 1월, 2월, 5월, 9월 식품접객업소에서 발생한 4건의 사례에서는 각각 2주, 3 주, 5주, 2주의 C. jejuni를 분리하였다.

\section{C. jejuni의 분리· 동정}

C. jejuni의 분리를 위해 modified Charcoal Cefoperazone Deoxycholate Agar (Oxoid, Basingstoke, UK)에 대변 검체를 멸 균된 면봉으로 도말하고 CampyGen (bioMérieux, Marcy l'Etoile, France)을 첨가하여 $42^{\circ} \mathrm{C}$ 에서 48 시간 미호기 배양하였 다. 배양 후 원형 또는 불규칙한 형태의 회백색 집락을 선별하 여 순수 분리하였고, catalase 양성, oxidase 양성인 균을 API Campy (bioMérieux, Marcy l'Etoile, France)로 시험하여 생화 학적 특성을 확인하였다. 또한 Campylobacter Triplex Detection kit (Kogenebiotech, Seoul, Korea) 및 질병관리본부 감염병실험 실진단[6]에 따른 hipO 유전자가 확인된 균을 C. jejuni로 최종 동정하였다.

\section{3. 항균제 감수성 검사}

항균제 감수성 검사는 Sensititre ${ }^{\mathrm{TM}}$ CAMPY (Thermo scientific, East Grinstead, UK)를 이용하여 제조사의 사용방법에 따 라 시험하고 minimum inhibitory concentration (MIC)을 측정하 였으며, 검사에 사용한 9종의 항균제는 erythromycin (ERY), chloramphenicol (CHL), ciprofloxacin (CIP), tetracycline (TET), telithromycin (TEL), gentamicin (GEN), azithromycin (AZI), streptomycin (STR), nalidixic acid (NAL)이다. 시험 균주는 혈 액한천배지에 $42^{\circ} \mathrm{C}$, 미호기성 조건에서 24 시간 배양한 후 Cation Adjusted Mueller-Hinton Broth w/TES (Thermo scien-

Table 1. Antimicrobial agents used for susceptibility testing of Campylobacter jejuni isolates

\begin{tabular}{llccc}
\hline \multirow{2}{*}{ Class } & \multicolumn{2}{c}{ Antimicrobial agent } & $\begin{array}{c}\text { Antimicrobial agent } \\
\text { concentration range (ug/mL) }\end{array}$ & \multicolumn{2}{c}{ MIC breakpoint (ug/mL) } \\
\cline { 4 - 4 } Aminoglycosides & Gentamicin & $0.12-32$ & $>2$ & Reference \\
& Streptomycin & $0.03-16$ & $>4$ & EURL-AR \\
Ketolides & Telithromycin & $0.015-8$ & $\geq 8$ & EURL-AR \\
Macrolides & Azithromycin & $0.015-64$ & $>4$ & NARMS \\
& Erythromycin & $0.03-64$ & $>4$ & EUCAST \\
Quinolones & Ciprofloxacin & $0.015-64$ & $>0.5$ & EUCAST \\
& Nalidixic acid & $4-64$ & $>16$ & EUCAST \\
Phenicols & Chloramphenicol & $0.03-64$ & $\geq 32$ & EURL-AR \\
Tetracyclines & Tetracycline & $0.06-64$ & $>2$ & NARMS \\
\hline
\end{tabular}

Abbreviations: EURL-AR, EU Reference Laboratory for Antimicrobial Resistance; NARMS, National Antimicrobial Resistance Monitoring System; EUCAST, European Committee on Antimicrobial Susceptibility Testing. 
tific, East Grinstead, UK)에 현탁하여 0.5 McFarland로 보정하 였다. 이 균액 $100 \mu \mathrm{L}$ 를 $5 \%$ laked horse blood (Thermo scientific, Basingstoke, $\mathrm{UK}$ )가 첨가된 $11 \mathrm{~mL} \mathrm{MHB}$ 에 접종하고 섞은 후 Sensititre ${ }^{\mathrm{TM}}$ CAMPY MIC plate (Thermo scientific)에 100 $\mu \mathrm{L}$ 씩 접종하여 $42^{\circ} \mathrm{C}$ 에서 48 시간 미호기 배양한 후 육안으로 판독하였다. Breakpoint는 Campylobacter에 대한 EUCAST (European Committee on Antimicrobial Susceptibility Testing, 2017), NARMS (National Antimicrobial Resistance Monitoring System), EURL-AR (EU Reference Laboratory for antimicrobial resistance, 2012) 기준에 따랐다(Table 1).

\section{PFGE 분석}

PFGE 분석은 국가 표준 실험실망인 PulseNet 방법에 따라 실험하였다. 순수 분리된 균을 멸균 면봉에 묻혀, $2 \mathrm{~mL}$ cell suspension TE $(0.85 \%$ Saline $)$ 에 넣어 VITEK colorimeter (bioMérieux, Loveland, CO, USA)를 사용하여 20\%의 투명도 로 현탁하였다. 현탁액 $200 \mu \mathrm{L}$ 를 $1.5 \mathrm{~mL}$ tube에 옮긴 다음, proteinase $\mathrm{K}(20 \mathrm{mg} / \mathrm{mL}) 20 \mu \mathrm{L}$ 와 $1.2 \%$ plug용 seakem gold agarose $200 \mu \mathrm{L}$ 를 넣어 섞은 후 바로 plug mold에 넣어 굳혔 다. $2 \mathrm{~mL}$ tube에 cell lysis buffer (0.5 M EDTA, $\mathrm{pH} 8.0$ : 1\% sodium- lauroyl-sarcosin)와 proteinase $\mathrm{K}(20 \mathrm{mg} / \mathrm{mL}) 30 \mu \mathrm{L}$ 가 첨가된 lysis solution $1.5 \mathrm{~mL}$ 에 굳은 plug를 넣고 $55^{\circ} \mathrm{C}$ 진탕 항 온수조에서 $100 \mathrm{rpm}$ 으로 1시간 동안 처리하였다. 세척용 완충 용액인 plug wash TE buffer (10 mM Tris pH 7.5 and $1 \mathrm{mM}$ EDTA, $\mathrm{pH} 7.5$ )를 넣어 $55^{\circ} \mathrm{C}$ 진탕 항온수조에서 40 분간 1 회, 20 분간 4회 처리하였다. 세척이 끝난 plug를 $1 \mathrm{~mm}$ 두께로 자 른 다음 $50 \mathrm{unit} / \mu \mathrm{L}$ SmaI 제한효소(NEB, UK)를 이용하여 $25^{\circ} \mathrm{C}$ 에서 4시간 동안 반응시키고 전기영동장치 $(\mathrm{CHEF}$ Mapper XA chiller, Bio Rad, Hercules, CA, USA)에 넣어 initial time $6.76 \mathrm{sec}$, final time $35.38 \mathrm{sec}$, 전압 $6 \mathrm{~V} / \mathrm{cm}$, angle $120^{\circ}$ 조건으 로 $14^{\circ} \mathrm{C}$ 에서 18 시간 동안 전기영동하였다. 전기영동 완료 후 SYBR Gold nucleic acid gel stain (Invitrogen, Eugene, OR, USA)을 gel에 넣어 30 분간 염색한 후 증류수를 이용하여 탈색 시켜 UV로 확인하였다. PFGE pattern은 Bionumerics 프로그램 (Bio-Rad Laboratories)을 이용하여 1.5\% tolerance, 1.5\% optimization dice coefficient로 유사도를 계산하였으며, UPGMA법 으로 유전적 유연관계를 분석하였다.

\section{RESULTS}

\section{C. jejuni의 분리 경향}

2014년부터 2017년 9월까지 부산 지역에서 분리된 C. jejuni 의 균주는 총 97주로, 급성설사질환 감시사업에서 분리된 61주 와 같은 기간 동안 발생한 식중독 중 C. jejuni가 원인균으로 분 리된 36주를 실험 대상으로 하였다. 급성설사질환 감시사업의
경우 4년간 부산 지역의 5 개 협력병원에서 의뢰된 2,992 건에서 61 주가 분리되어 평균 $2.0 \%$ 의 분리율을 나타내었고 월별 분리 율은 급성설사질환 감시사업과 식중독 발생 건 모두 하절기인 6월에서 9월에서 높게 나타났다(Fig. 1).

\section{C. jejuni의 항균제 감수성 결과}

설사환자에서 분리된 97주 중 식중독 분리주 36주는 같은 식 중독 case에서 같은 항균제 패턴을 나타내어 표본으로 1 주씩 처리하여, 급성설사질환 감시사업에서 분리된 61주와 식중독 균주 표본 5 주를 포함하여 66 주에 대해 9종류의 항균제에 대한 내성 정도를 MIC (minimal inhibitory concentration)로 확인하 였다.

C. jejuni 66주는 nalidixic acid에 90.9\%, ciprofloxacin에 89.4\%로 quinolone계 항균제 2종류에 높은 내성을 나타내었고, 다음으로 tetracycline에 $13.6 \%$ 내성을 나타내었다. 또한 macrolides계 항균제인 azithromycin과 erythromycin에 각 $3.0 \%$, aminoglycosides계 항균제인 streptomycin에는 $1.5 \%$ 내성이었으며, gentamicin, chloramphenicol, telithromycin에는 모두 감수성이 었다(Table 2).

항균제에 대한 다제내성 양상을 살펴보면 C. jejuni 66 주 중 $92.4 \%$ 인 61주가 1종류 이상의 항균제에 내성을 나타내었으며, 2 개 계열 이상에 내성을 나타내는 다제내성균은 12 주 $(18.2 \%)$ 로 공통적으로 quinolone계 항균제를 포함하고 있었고, 3 개 계 열에 내성을 나타내는 균주도 1 주 $(1.5 \%)$ 있었다(Table 3$)$.

\section{PFGE에 의한 유전형 분석}

분리된 97주 중 급성설사질환 감시사업에서 분리된 61주와 $5 \mathrm{case}$ 의 식중독에서 분리된 균주 표본 5 주를 포함하여 66 주에 대해 SmaI 제한효소로 처리한 후 PFGE를 실시하였고, 유전적 유사성이 $80 \%$ 이하인 경우에는 서로 다른 cluster로 분리하였

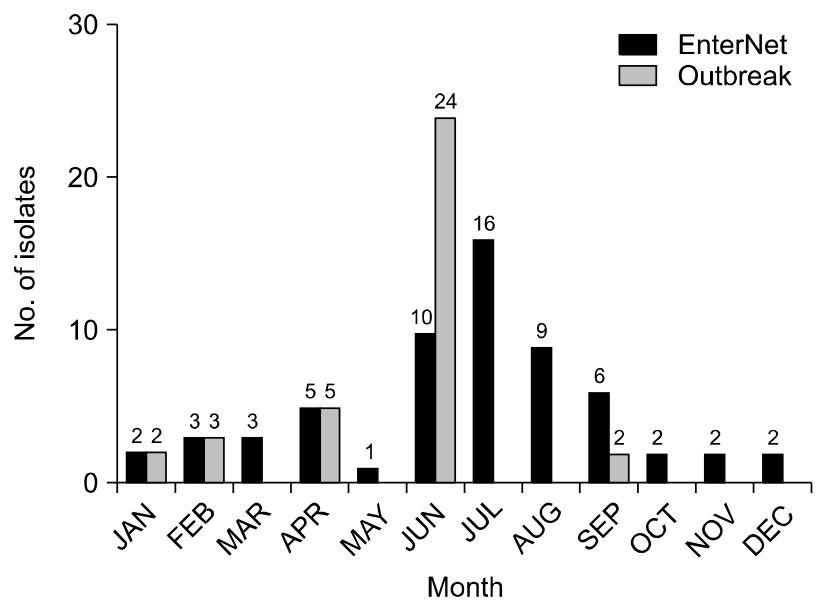

Fig. 1. Prevalence of $C$. jejuni isolates from diarrhea patients by month. 
Table 2. Antimicrobial resistance rate and minimum inhibitory concentration (MIC) distribution of each agent in 66 . jejuni

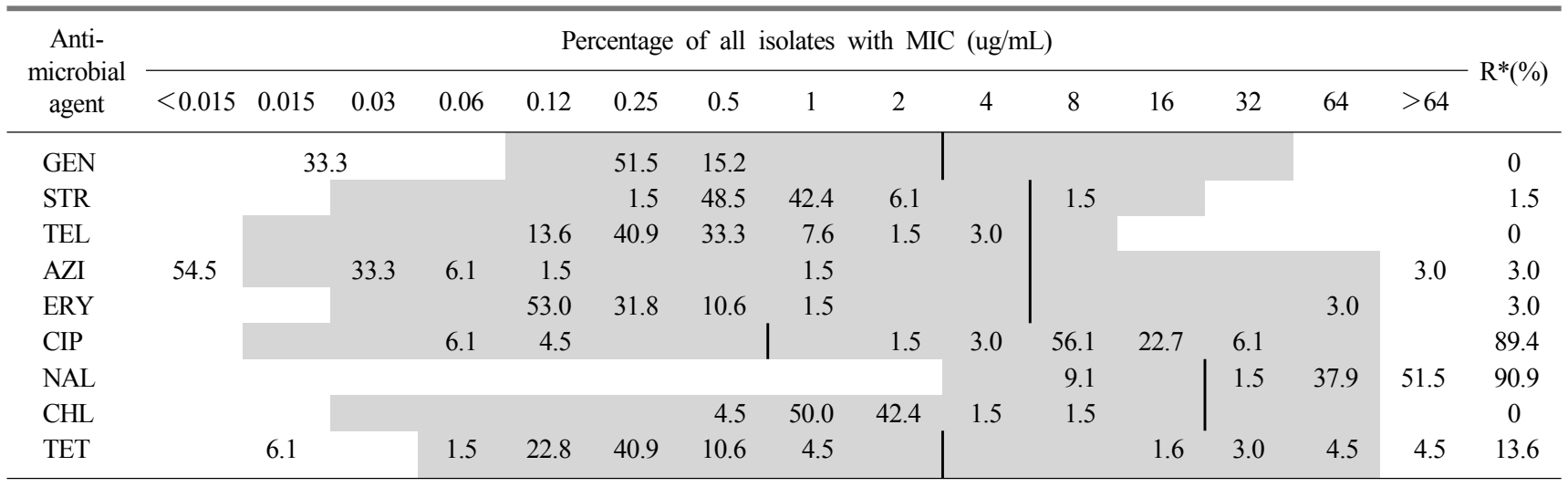

*R: Resistance rate.

Abbreviations: GEN, gentamicin; STR, streptomycin; TEL, telithromycin; AZI, azithromycin; ERY, erythromycin; CIP, ciprofloxacin; NAL, nalidixic acid; CHL, chloramphenicol; TET, tetracycline.

A thick black line indicates the breakpoint and gray shadow area indicates the test range (ug/mL) of each antimicrobial agent.

Table 3. Antimicrobial resistance patterns of $C$. jejuni $(\mathrm{n}=66)$

\begin{tabular}{|c|c|c|c|c|}
\hline $\begin{array}{l}\text { No. of } \\
\text { resistance }\end{array}$ & Antimicrobial class & Resistance patterns & \multicolumn{2}{|c|}{ No. of isolates $(\%)$} \\
\hline 0 & & & $5(7.6)$ & $5(7.6)$ \\
\hline \multirow[t]{3}{*}{1} & Quinolones & CIP & $2(3.0)$ & $49(74.2)$ \\
\hline & & NAL & $3(4.5)$ & \\
\hline & & CIP-NAL & $44(66.7)$ & \\
\hline \multirow[t]{3}{*}{2} & Quinolones-Tetracyclines & CIP-NAL-TET & $8(12.1)$ & $11(16.7)$ \\
\hline & Quinolones-Penicoles & CIP-NAL-CHL & $1(1.5)$ & \\
\hline & Quinolones-Macrolides & CIP-NAL-AZI-ERY & $2(3.0)$ & \\
\hline 3 & Quinolones-Aminoglycosides-Tetracyclines & CIP-NAL-STR-TET & $1(1.5)$ & $1(1.5)$ \\
\hline
\end{tabular}

Abbreviations: see Table 2.

다. Dendrogram 비교분석 결과 17 개 cluster로 분류되었는데 이 중 cluster 11 이 25주(37.9\%)로 가장 많은 비율을 차지하였으며 다음으로는 cluster 10 이 8주(12.1\%), cluster 7이 7주(10.6\%)였 다(Fig. 2).

\section{DISCUSSION}

부산 지역 급성설사질환 감시사업에서 C. jejuni의 4년간 평 균 분리율은 $2.0 \%$ 였으며, 연도별 분리율은 2014년 $0.9 \%, 2015$ 년 $1.5 \%$, 2016년과 2017년 9월까지 각 3.7\%씩으로 매년 분리 율이 증가하였다. 이는 질병관리본부의 2012년부터 2015년 급 성설사질환 실험실 감시사업 결과[5] 전국 설사환자 검체 70,406건 중 716주의 Campylobacter spp.를 분리하였고 연평균 분리율은 2012년 $0.67 \%$ 에서 2015년 $1.51 \%$ 로 약 2 배 이상 증가 하였다고 보고한 자료와 일치하였다.

월별 분리양상은 급성설사질환 감시사업과 식중독 발생 건 모두 하절기인 6월에서 9월까지 가장 분리율이 높았으며, 이와
같은 결과는 국내의 여러 보고[7-10] 뿐만 아니라 국외[1,2]에 서도 같은 경향이었다. 또한 질병관리본부 자료에 따르면 주요 식중독 원인 병원체인 E. coli나 Salmonella에 비해 Campylobacter의 경우 계절에 따라 분리율이 유의하게 증가한다고 보 고[5]하고 있어, 향후 기후 온난화로 인한 Campylobacter 식중 독 증가가 예상되므로 Campylobacter 식중독의 주요 원인인 닭 고기의 위생적인 처리, 교차오염 방지 등에 대한 주의가 더욱 필요할 것이다.

Campylobacter 감염은 대부분 자기제한적이고 탈수와 전해 질 균형 유지를 위한 보조 요법 이외의 치료는 하지 않지만 면 역 저하 환자, 증상이 심각하거나 외인성 감염이 있는 환자의 경우 항균제 치료를 하고 있는데 주로 ciprofloxacin이 널리 사 용되었다. Quinolone계 항균제인 ciprofloxacin은 복제, 전사, 재 조합 등에 필요한 효소인 DNA gyrase와 topoisomerase IV를 주요 타켓으로 하고 있으며 근래 이 항균제에 대한 내성 보고 가 증가하고 있는 추세여서 현재는 erythromycin, azithromycin 과 같은 macrolides계 항균제 치료를 선호하고 있다. Macrolide 


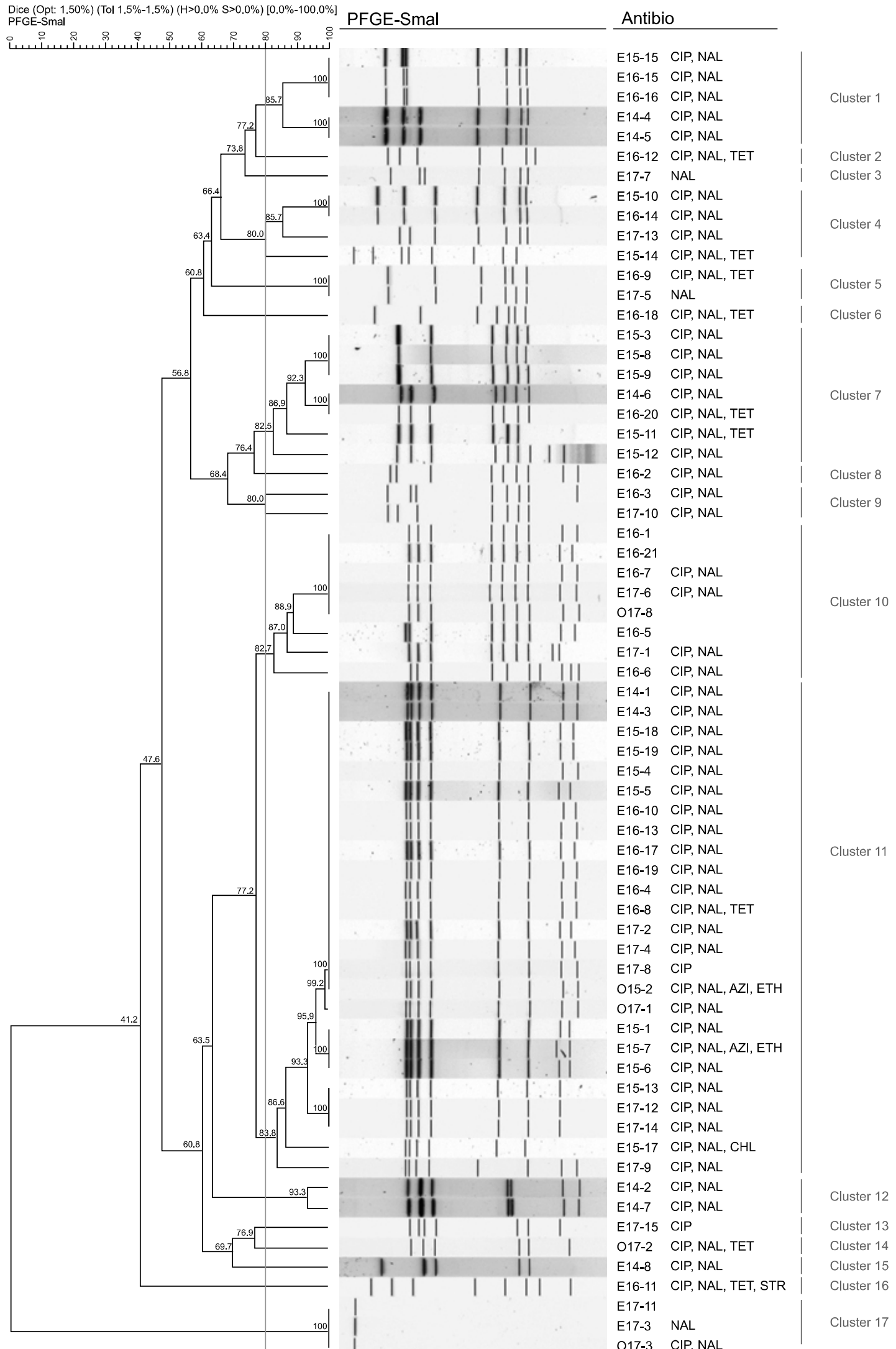

Fig. 2. Dendrogram of SmaI PFGE patterns for $C$. jejuni isolates from diarrhea patients. 
계 항균제는 주로 $23 \mathrm{~S} \mathrm{rRNA}$ 와 ribosomal protein에 결합하여 단백질합성을 저해해 항균 효과를 나타내는데 성장 촉진과 치 료의 이유로 동물 산업에서 사용중이고, 일부 국가에서 높은 내성을 지닌다고 보고[11,12]되고 있으며, macrolide계 항균제 에 내성인 Campylobacter는 감수성 균주에 비해 인체 감염 시 부작용의 위험, 침습성 질환으로 발전, 사망 등의 위험요소가 더 높은 것으로 보고[13]되었다.

국가항균제내성정보 2014년 연보[14]에 따르면 국내에서 분 리되는 C. jejuni의 nalidixic acid와 ciprofloxacin 내성률은 2013 년 기준 93.5\%, 91.3\%로 내성률이 높으며, azithromycin과 erythromycin에서는 내성주가 확인되지 않았다고 보고하였다. 그 리고 가금류 및 가축에서 분리한 C. jejuni의 항균제 감수성에 관한 연구 중 Chae 등[13]은 2010년 가축 및 도축장 식육(소, 돼지, 닭)에서 분리한 균주의 경우 모든 축종에서 ciprofloxacin, nalidixic acid에 내성이었고, erythromycin의 내성률은 닭에서 $7.0 \%$ 였으며, 국내 가축 및 식육 분리주에서의 내성률이 다른 나라에 비해 높고 사람에게 전달 가능성이 있다고 하였다.

본 연구에서의 내성률은 ciprofloxacin $89.4 \%$, nalidixic acid 90.9\%로 quinolone계 내성률이 높은 수준이었고, azithromycin 과 erythromycin에서도 $3.0 \%$ 의 내성률을 나타내었다. Park 등 [7]은 2005년-2006년 10월까지 부산지역 설사환자에서 분리한 C. jejuni의 항균제 내성률은 ciprofloxacin 37\%, nalidixic acid $33.3 \%$ 였으며, erythromycin에는 모든 균주가 감수성으로 보고 하였는데, 실험방법이나 판독 기준에서 차이점이 있으나 본 연 구 결과와 비교해 보았을 때 10 여년 동안 부산지역 설사환자에 서 분리된 C. jejuni의 quinolone계 항균제 내성률은 더 높아졌 으며, macrolide계 항균제에 대해서도 내성이 나타났음을 알 수 있었다. 이는 국내 항균제 사용 실태 및 주요 병원균의 항균제 내성에 관한 연구[15]에서 부산지역의 항균제 처방 비율이 2002년과 2013년 비교 시 quinolone계는 $8 \%$ 에서 $12 \%$, macrolide계는 $7 \%$ 에서 $15 \%$ 로 증가한 점, 항균제 내성이 높은 축산물 의 소비량 증가 등 여러 요인이 작용했을 것이라고 생각한다. Quinolone계 항균제 내성률 증가는 미국[16], 영국[17], 네덜란 드[18] 등 다수의 연구에서 보고되었으며, 국내 경향도 최근 보 고된 경기도[8]의 경우 nalidixic acid, ciprofloxacin 각 $95.2 \%$, 인천[10]은 nalidixic acid $93.1 \%$, ciprofloxacin $96.8 \%$ 로 본 연구 와 비슷한 수준이었다. 또한 macrolide계 항균제 내성의 경우, 미국[19]의 최근 보고에서 erythromycin $4 \%$ 이하, 스페인[20] $3.8 \%$, 국내의 경기도 $[8] 2.4 \%$ 로 본 연구 결과와 비슷한 경향을 나타내었다. 중증의 캠필로박터증 치료제로 사용하는 gentamicin에 대한 내성은 아직까지 낮은 것으로 보고[1]되고 있으며, 본 연구에서도 gentamicin에는 모든 균주가 감수성이었다.

항균제 다제내성 양상에 대해 살펴보면 2계열 이상에 내성 을 나타내는 다제내성균은 12 주(18.2\%)로 공통적으로 quinolone계 항균제인 CIP-NAL 패턴을 포함하고 있었고, 3 계열에
내성을 나타내는 균주도 1주 $(1.5 \%)$ 있었다. 또한 quinolone계 와 macrolide계에 내성을 나타내는 CIP-NAL-AZI-ERY 패턴의 균주가 2주 $3.0 \%$ )였는데, 이는 급성설사질환 감시사업 2015년 6월에 분리된 1주와 2015년 7월 고등학교에서 발생한 집단 식 중독 건에서 분리한 24 주 모두에서 나타난 패턴이었다. 이와 같이 사람에서 Campylobacter 치료제로 사용되는 quinolone계 와 macrolide계 항균제에 동시에 내성을 나타내는 내성 균주는 사람에서 적절한 치료제가 없어 심각한 문제를 일으킬 수 있다 는 보고[21]가 있으므로 항균제 사용에 더욱 주의를 기울여야 하겠다.

항균제 감수성 실험과 관련하여 본 연구에서 사용한 항균제 감수성 패널은 기존의 배지희석법에 비해 사용하기 편리한 장 점이 있으나, 9 종류의 항균제에 대해 $64 \mathrm{ug} / \mathrm{mL}$ 농도까지만 판 독 가능하여 항균제 종류의 선택이 어렵고 $64 \mathrm{ug} / \mathrm{mL}$ 이상의 검 사결과에서는 어떤 농도까지 내성을 나타내는지 여부는 알 수 없는 한계점이 있었다. 그리고 Campylobacter에 대한 breakpoint의 경우 CLSI, EUCAST, NARMS 등 기관마다 항균제 종 류 및 기준이 다양하며, 어떠한 기준으로 판독하였는지 제시되 어 있지 않은 참고문헌의 경우 단순한 내성률 또는 내성 표기 만으로는 결과 비교에 어려운 점이 있으므로 항균제 내성 기준 및 표기의 표준화 등이 필요할 것으로 생각한다.

$\mathrm{PFGE}$ 에 따른 유전형 분석에서 급성설사질환 분리주 61주와 5 case의 식중독 표본주 5 주는 17 개의 다양한 cluster로 분류되 었으며, 가장 많은 비율을 차지한 Cluster 11의 경우 2014년부 터 2017년까지 급성설사질환 감시사업에서 매년 분리된 23주 와 2015년 7월과 2017년 1월 식중독 분리주가 포함되어 있어 부산지역에서 분리되는 C. jejuni의 주요 유전형 패턴임을 알 수 있었다. 또한 cluster 14에는 2017년 2월 식중독 분리주, cluster 17에는 2017년 5월 식중독 분리주와 2017년 급성설사 질환 감시사업에서 분리된 2주가 포함되어 있었다.

본 연구에서는 2014년부터 2017년 9월까지 부산지역 설사환 자에서 C. jejuni의 분리 경향을 알아보고, 항균제 감수성 현황 을 조사하여 주요 항생제에 대한 내성률과 다제내성 양상을 파 악하였으며, PFGE를 통한 유전자형 분석을 통해 유행 패턴을 조사하였다. 향후 증가가 예상되는 C. jejuni로 인한 식품매개 질환 발생 시 신속한 역학적 연관성 파악, 적절한 항균제 사용 과 내성균 관리를 위해 지속적인 모니터링과 자료 축적이 필요 하다고 생각한다.

\section{REFERENCES}

1. Kaakoush NO, Castaño-Rodríguez N, Mitchell HM, Man SM. Global epidemiology of Campylobacter infection. Clin Microbiol Rev 2015;28:687-720.

2. Silva J, Leite D, Fernandes M, Mena C, Gibbs PA, Teixeira P. Campylobacter spp. as a foodborne pathogen: a review. Front 
Microbiol 2011;2:200.

3. Allos BM. Campylobacter jejuni infections: update on emerging issues and trends. Clin Infect Dis 2001;32:1201-6.

4. Vanhoof R, Vanderlinden MP, Dierickx R, Lauwers S, Yourassowsky E, Butzler JP. Susceptibility of Campylobacter fetus subsp. jejuni to twenty-nine antimicrobial agents. Antimicrob Agents Chemother 1978;14:553-6.

5. Jung SM, Kim NO, Na HY, Hong SH, Chung GT. Prevalence of Campylobacter causing acute diarrhea in Korea, 2012-2015. Pubic Health Wkly Rep 2016;9:526-30.

6. Korea Centers for Disease Control and Prevention. Infectious Disease Laboratory Diagnosis; Disease-Specific Protocol. 3rd ed. Seoul: National Institute of Health; 2005.

7. Park EH, Kim JA, Choi SH, Bin JH, Cheigh HS, Suk DH, et al. Isolation and antimicrobial susceptibility of Campylobacter jejuni from diarrhea patients. J Life Sci 2007;17:811-5.

8. Hur ES, Park PH, Kim JH, Son JS, Yun HJ, Lee YE, et al. Genetic properties and antimicrobial resistance of Campylobacter jejuni isolates from diarrhea patients in Gyeonggi-do. Korean $\mathbf{J}$ Microbiol 2013;49:228-36.

9. Kim WH, Choi OK, Jeong JA, Park SH, Lee YE, Park GH, et al. Genetic analysis of Campylobacter jejuni isolates from diarrhea patients in Gyeonggi-do. Korean J Microbiol 2018;54:31-7.

10. Kim JS, Lee MY, Kim SJ, Jeon SE, Cha I, Hong S, et al. High-level ciprofloxacin-resistant Campylobacter jejuni isolates circulating in humans and animals in Incheon, Republic of Korea. Zoonoses Public Health 2016;63:545-54.

11. Wieczorek K, Szewczyk R, Osek J. Prevalence, antimicrobial resistance, and molecular characterization of Campylobacter jejuni and $C$. coli isolated from retail raw meat in Poland. Vet Med 2012;57:293-9.

12. Kim NH, Chae HS, Kang YI, Shin BW, Choi NH, Kim HB. Prevalence and antimicrobial resistance patterns of Campylobacter jejuni from duck feces. Korean J Vet Serv 2013;36:57-60.
13. Chae MH, Nam HM, Jang GC, Kim HJ, Kim SR, Jung SC, et al. Antimicrobial resistance in Campylobacter jejuni and Campylobacter coli isolated from food animals and raw meats in slaughterhouse in Korea during 2010. Korean J Vet Public Health 2013;35: 239-45.

14. Korea Centers for Disease Control \& Prevention and Korea National Institute of Health. Korean Antimicrobial Resistance Monitoring System 2014 Annual Report. Osong: KNIH; 2016.

15. National Health Insurance Service Ilsan Hospital Institute of Health Insuarance \& Clinical Research. https:/www.nhimc.or.kr/ openInfo/management/audit/hospital_41_disc_audit05_1.do[Online] (last visited on 16 December 2017).

16. Nachamkin I, Ung H, Li M. Increasing fluoroquinolone resistance in Campylobacter jejuni, Pennsylvania, USA,1982-2001. Emerg Infect Dis 2002;8:1501-3.

17. Dingle KE, Clarke L, Bowler IC. Ciprofloxacin resistance among human Campylobacter isolates 1991-2004: an update. J Antimicrob Chemother 2005;56:435-7.

18. van Hees BC, Veldman-Ariesen MJ, de Jongh BM, Tersmette M, van Pelt W. Regional and seasonal differences in incidence and antibiotic resistance of Campylobacter from a nationwide surveillance study in the Netherlands: an overview of 2000-2004. Clin Microbiol Infect 2007;13:305-10.

19. US Food and Drug Administration. NARMS Integrated Report: 2014. The National Antimicrobial Resistance Monitoring System: Enteric Bacteria. Silver Spring: US FDA; 2014.

20. Pérez-Boto D, López-Portolés JA, Simón C, Valdezate S, Echeita MA. Study of the molecular mechanisms involved in high-level macrolide resistance of Spanish Campylobacter jejuni and Campylobacter coli strains. J Antimicrob Chemother 2010;65: 2083-8.

21. Hoge CW, Gambel JM, Srijan A, Pitarangsi C, Echeverria P. Trends in antibiotic resistance among diarrheal pathogens isolated in Thailand over 15 years. Clin Infect Dis 1998;26:341-5. 
$=$ 국문초록=

\section{부산지역 설사환자에서 분리한 Campylobacter jejuni의 항균제 감수성과 유전자형 분석}

부산광역시 보건환경연구원 감염병연구부 미생물팀

박선희, 김병준, 권영희, 황인영, 성경혜, 박은희, 진성현

배경: Campylobacter는 식품매개질환의 중요한 원인균으로, 본 연구에서는 부산지역 설사환자에서 분리한 Campylobacter jejuni의 분리경향, 항균제 내성률, 유전자형 분석에 대해 조사하였다.

방법: 2014년부터 2017년 9월까지 급성설사질환 감시사업 및 5건의 식중독 사례에서 97주의 Campylobacter jejuni를 분리 하였다. 항균제 감수성 검사는 9종류의 항균제(ciprofloxacin (CIP), nalidixic acid (NAL), tetracycline (TET), chloramphenicol, azithromycin (AZI), erythromycin (ERY), streptomycin (STR), gentamicin, telithromycin)에 대하여 액체배지미량 희석법으로 실시하였고, 유전자형은 pulsed-field gel electrophoresis (PFGE)로 분석하였다.

결과: Campylobacter jejuni의 4년간 평균 분리율은 $2.0 \%$ 였으며 해마다 분리율은 증가하였다. 항균제 내성률은 NAL $90.9 \%$, CIP $89.4 \%$, TET $13.6 \%$, AZI와 ERY 각 3.0\%, STR $1.5 \%$ 순이었고, 다제내성률은 $18.2 \%$ 였으며 다제내성균주 모두 quinolone계 항균제(CIP-NAL)를 포함하고 있었다. SmaI 제한효소로 처리한 PFGE 패턴은 모두 17개 cluster로 분류되었으 며 이 중 cluster 11이 부산지역에서 분리되는 Campylobacter의 주요 유전자형 패턴이었다.

결론: 본 연구는 적절한 항균제 사용과 항균제 내성 관리를 위한 유용한 자료를 제시하며, 향후 증가가 예상되는 Campylobacter로 인한 식중독의 역학 조사를 위한 자료 축적에 도움이 될 것이다. [Ann Clin Microbiol 2019;22: 42-49]

교신저자 : 박선희, 46616 , 부산시 북구 함박봉로 140 번길 120 부산광역시 보건환경연구원 감염병연구부 미생물팀 Tel: 051-309-2822, Fax: 051-309-2829

E-mail: psh0215@korea.kr 